Finanse, Rynki Finansowe, Ubezpieczenia nr 3/2017 (87), cz. 1

\title{
Przebieg realizacji czynności audytowych w jednostkach administracji rządowej
}

\author{
Jadwiga Wawer-Bernat
}

\begin{abstract}
Streszczenie: $\mathrm{Cel}$ - Przedstawienie przebiegu realizacji czynności audytowych w jednostkach sektora administracji rządowej.

Metodologia badania - Analiza regulacji prawnych, literatury oraz opracowań Ministerstwa Finansów w zakresie oceny funkcjonowania audytu wewnętrznego w jednostkach sektora finansów publicznych.

Wynik-Zestawienie informacji na temat realizacji zadań audytowych w jednostkach administracji rządowej w latach 2011-2015.

Oryginalność/wartość - Zwrócenie uwagi na aspekt doskonalenia pomiaru efektowności czynności doradczych.
\end{abstract}

Słowa kluczowe: audyt wewnętrzny, funkcja doradcza, sektor administracji rządowej, czynności audytowe

\section{Wprowadzenie}

Przystąpienie Polski do Unii Europejskiej zapoczątkowało między innymi rozwój audytu wewnętrznego w jednostkach sektora finansów publicznych. Podstawowym celem audytu wewnętrznego jest badanie gospodarności, efektywności i skuteczności działań jednostki. Od tych czynników zależy prawidłowe działanie systemu kontroli i procesów zarządzania ryzykiem. Audyt wewnętrzny przynosi wartość dodaną przez ujawnianie nieprawidłowości oraz wskazywanie sposobów podniesienia jakości i wydajności pracy w celu niwelowania skutków zagrożenia efektywności funkcjonowania danej jednostki. Audyt wewnętrzny pełni w jednostkach sektora finansów publicznych ważną rolę doradczą.

Celem artykułu jest przedstawienie przebiegu realizacji audytu wewnętrznego $\mathrm{w}$ jednostkach sektora finansów publicznych w latach 2011-2015. Badanie przeprowadzono na podstawie oceny funkcjonowania audytu wewnętrznego w jednostkach sektora administracji rządowej, przeprowadzonej przez Ministerstwo Finansów.

\section{Rola audytu wewnętrznego}

$Z$ definicji audytu wewnętrznego wynikają jego funkcje i rola w systemie zarządzania jednostką. Audyt wewnętrzny w sposób proaktywny, niezależny, profesjonalny i obiektywny

\footnotetext{
* dr Jadwiga Wawer-Bernat, Uniwersytet Szczeciński, WNEiZ, Instytut Rachunkowości, e-mail:jwawer@wneiz.pl.
} 
ocenia efektywność systemu kontroli wewnętrznej i procesów zarządzania ryzykiem (Saunders, 2002, s. 52). Rolą audytu jest ocenianie systemu zarządzania pod kątem prawidłowości działania jednostki w zakresie efektywności wykorzystywania powierzonych zasobów Skarbu Państwa, a także skuteczności funkcjonowania kontroli zarządczej. Zadania audytu wewnętrznego obejmują generalnie trzy grupy: 1) zadania operacyjne (planowanie, analizę ryzyka, realizację zadań audytowych, sprawozdawczość, monitoring); 2) zadania oceniające (raportowanie i przedstawianie uwag i wniosków); 3) zadania doradczo-usprawniające (rekomendowanie ulepszeń systemów i procesów zarzadzania ryzykiem, kontroli zarządczej i zarzadzania jednostką). Zmiany w ustawie o finansach publicznych, obejmujące między innymi sposób definiowania audytu wewnętrznego uwypukliły, obok funkcji zapewniającej, jego rolę doradczą - jej realizacja ma zapewnić wniesienie do działalności jednostki wartości dodanej, mającej na celu usprawnienie struktury jednostki, co umożliwi wygenerowanie większego zysku lub osiągnięcia tego samego efektu przy niższych nakładach (Kaczmarczyk, Kaczmarczyk, 2012). Uregulowania w zakresie audytu wprowadzane w kolejnych ustawach o finansach publicznych przedstawiono w tabeli 1.

\section{Tabela 1}

Pojęcie audytu wewnętrznego w ustawie o finansach publicznych

\begin{tabular}{|c|c|}
\hline Akt prawny & Definicja audytu wewnętrznego \\
\hline $\begin{array}{l}\text { Ustawa } \mathrm{z} \text { dnia } 27 \text { lipca } \\
2001 \mathrm{r} \text {. o zmianie ustawy } \\
\text { o finansach publicznych, } \\
\text { art. } 35 \mathrm{c} \text {. }\end{array}$ & $\begin{array}{l}\text { ogół działalności, przez które kierownik jednostki zyskuje obiektywną i niezależną } \\
\text { ocenę funkcjonowania jednostki w zakresie gospodarki finansowej pod względem } \\
\text { legalności, gospodarności, rzetelności, a także przejrzystości i jawności }\end{array}$ \\
\hline $\begin{array}{l}\text { Ustawa z dnia } 30 \text { czerwca } \\
2005 \text { r. o finansach } \\
\text { publicznych, art. } 48, \text { ust. } 1 .\end{array}$ & $\begin{array}{l}\text { ogół działań obejmujący: } \\
\text { - niezależne badanie systemu zarządzania i kontroli w jednostce, w tym procedur } \\
\text { kontroli finansowej, w wyniku którego kierownik jednostki uzyskuje obiektywną, } \\
\text { niezależną ocenę adekwatności, efektywności i skuteczności tych systemów, } \\
\text { - czynności doradcze, w tym składanie wniosków, mające na celu usprawnienie } \\
\text { funkcjonowania jednostki }\end{array}$ \\
\hline $\begin{array}{l}\text { Ustawa z dnia } 27 \text { sierpnia } \\
2009 \text { r. o finansach } \\
\text { publicznych, art. } 272 \text {, ust. } 1 .\end{array}$ & $\begin{array}{l}\text { działalność niezależna i obiektywna, której celem jest wspieranie ministra } \\
\text { kierującego działem lub kierownika jednostki w realizacji celów i zadań przez } \\
\text { systematyczną ocenę kontroli zarządczej oraz czynności doradcze }\end{array}$ \\
\hline
\end{tabular}

Źródło: opracowanie własne na podstawie ustawy o finansach publicznych.

Audyt wewnętrzny przynosi wartość dodaną przez wskazywanie sposobów na podniesienie jakości i wydajności pracy oraz przez ujawnianie słabych stron organizacji.

\section{Zakres prac audytowych}

Zakres podmiotowy audytu wewnętrznego określa art. 274, ust. 1 ustawy o finansach publicznych (Dz.U. 2016, poz. 1870). W myśl jego postanowień jednostkami zobligowanymi do prowadzenia audytu są: 1) Kancelaria Prezesa Rady Ministrów; 2) ministerstwa; 
3) urzędy wojewódzkie; 4) izby administracji skarbowej; 5) ZUS; 6) KRUS; 7) NFZ. Dodatkowo także państwowe jednostki budżetowe, uczelnie publiczne, samodzielne publiczne jednostki opieki zdrowotnej, agencje wykonawcze oraz państwowe fundusze celowe, jeśli kwota przychodów lub kosztów w ich planie finansowym przekroczyła $40 \mathrm{mln}$ zł (Rozporządzenie Ministra Finansów z dnia 24 czerwca 2006 r. w sprawie kwot, których przekroczenie powoduje obowiązek prowadzenia audytu wewnętrznego $\mathrm{w}$ jednostkach sektora finansów publicznych; Dz.U. nr 112, poz. 763).

Głównym zadaniem audytora wewnętrznego jest systematyczna ocena kontroli zarządczej w kontekście adekwatności, efektywności i skuteczności zarządzania poszczególnymi obszarami działalności danej jednostki, na podstawie przeprowadzonego badania ich zgodności z przepisami prawa i wewnętrznymi procedurami. Na zakres pracy audytora wewnętrznego, zgodnie z obowiązującą ustawą o finansach publicznych, składa się obiektywne i niezależne zbadanie systemu zarządzania i kontroli zarządczej w jednostce oraz czynności doradcze mające na celu usprawnienie działania jednostki. W jednostkach sektora finansów publicznych zakres czynności audytowych obejmuje (Brzozowska, 2008):

- identyfikację i aktualizację zachodzących procesów i funkcjonujących systemów,

- analizę ryzyka i opracowanie na jej podstawie planów audytu,

- stworzenie metodyki przeprowadzenia audytu,

- wykonywanie określonych zadań audytowych,

- sporządzanie sprawozdań z audytu,

- opracowanie karty audytu i jego procedur,

- świadczenie czynności doradczych z zachowaniem zasady, że audytor wewnętrzny nie przejmuje obowiązków kierownictwa.

Prawidłowe przeprowadzenie czynności audytorskich pozwala kierownikowi jednostki uzyskać pewność, że wszystkie zachodzące w niej procesy przebiegają prawidłowo. To znaczy (Szymańska, 2012, s. 17), że: 1) cele jednostki są odpowiednio realizowane; 2) zasady i procedury wynikające $z$ obowiązujących przepisów prawa są wdrażane, przestrzegane i wprowadzone przez kierownika jednostki; 3) przyjęty system kontroli zarządczej jest adekwatny i skuteczny, co umożliwia dokonanie prawidłowej oceny działalności jednostki.

Niezależność i obiektywizm audytora, które wynikają z międzynarodowych standardów' opracowanych przez IIA, a wdrożonych dla jednostek sektora finansów publicznych, wpływają na jakość i efektywność audytu². Jakość i efektywność audytu wewnętrznego

\footnotetext{
${ }^{1} \mathrm{~W}$ jednostkach sektora finansów publicznych obowiązują opracowane przez IIA (The Institute of Internal Auditors - Międzynarodowe Stowarzyszenie Audytów powołane w 1941 r. w USA) Międzynarodowe Standardy Praktyki Zawodowej Audytu Wewnętrznego; określają one cechy audytu i audytorów, opisują charakter działań audytu wewnętrznego oraz kryteria służące do ich oceny, przypisują cechy i kryteria jakościowe oceny określonym rodzajom zadań audytowych.

${ }^{2}$ W myśl międzynarodowych standardów audyt to działalność niezależna i obiektywna, której celem jest przysporzenie wartości i usprawnienie działalności operacyjnej organizacji. Polega na systematycznej i dokonywanej w uporządkowany sposób ocenie procesów zarządzania ryzykiem, kontroli i ładu organizacyjnego, i przyczynia się do poprawy ich działania. Pomaga organizacji osiągnąć zapewnienie o skuteczności tych procesów poprzez doradztwo. Wynika z tego, że rolą audytu jest doskonalenie organizacji (Czerwiński, 2004, s. 157).
} 
uzależniona jest od czasu pracy poświęconego na wykonanie czynności wchodzących w jego zakres. Zalicza się do nich (Rozporządzenie Ministra Finansów z dnia 4 września 2015 r., art. 2):

- czynności zapewniające, to znaczy działania podejmowane w celu dostarczenia niezależnej i obiektywnej oceny kontroli zarządczej,

- czynności doradcze, prowadzące do wydania opinii mającej na celu usprawnienie funkcjonowania jednostki,

- czynności sprawdzające, czyli służące dokonaniu oceny sposobu wdrożenia i skuteczności zaleceń zrealizowanych przez podlegającą badaniu jednostkę.

Rozmiar czynności audytowych w sektorze administracji rządowej w latach 2011-2015 zaprezentowano w tabeli 2 .

\section{Tabela 2}

Liczba działań audytowych w jednostkach administracji rządowej w latach 2011-2015

\begin{tabular}{|c|c|c|c|c|}
\hline Czynności audytowe wynikających z planu audytu & 2011 & 2012 & 2014 & 2015 \\
\hline Liczba jednostek administracji rządowej objętych badaniem & 606 & 575 & 565 & 574 \\
\hline Stopień realizacji planu audytowego (\%) & 70,00 & 69,00 & 72,00 & 70,00 \\
\hline $\begin{array}{l}\text { Czynności zapewniające } \\
\text { liczba zrealizowanych zadań }\end{array}$ & 1254 & 1280 & 1321 & 1460 \\
\hline $\begin{array}{l}\text { Czynności doradcze } \\
\text { liczba przeprowadzonych czynności }\end{array}$ & 258 & 416 & 528 & 537 \\
\hline $\begin{array}{l}\text { Czynności sprawdzające } \\
\text { liczba przeprowadzonych czynności }\end{array}$ & 654 & 673 & 734 & 767 \\
\hline $\begin{array}{l}\text { Udział czynności doradczych w łącznej liczbie przeprowadzonych } \\
\text { działań (\%) }\end{array}$ & 11,91 & 17,56 & 20,44 & 19,43 \\
\hline
\end{tabular}

Źródło: opracowanie własne na podstawie Departament (2012, 2012a, 2013, 2015, 2015a, 2016, 2016a).

Z danych zawartych w tabeli 2 wynika, że audytorzy poświęcają na czynności bezpośrednio związane $\mathrm{z}$ audytem około $70 \%$ możliwego czasu. Według informacji o realizacji zadań z zakresu audytu wewnętrznego w 2015 roku sytuacja taka wystąpiła w 372 jednostkach administracji rządowej na 574 jednostek, które przekazały taką informację. Największy przyrost w badanym okresie nastąpił w przeprowadzonych czynnościach doradczych. W 2015 roku wyniósł on 108,13\% w relacji do 2011 roku. Wzrost zrealizowanych czynności zapewniających osiągnął natomiast $16,43 \%$, a czynności sprawdzających $17,28 \%$. W analizowanym okresie wystąpiło także stopniowe zwiększenie udziału czynności doradczych w łącznej liczbie działań audytowych z 11,91\% w 2011 roku do 19,43\% w 2015 roku. Niski stopień realizacji zadań sprawdzających wskazuje na małą skuteczność zaleceń usprawnienia kontroli zarządczej oraz eliminowania niedoskonałości w tym zakresie.

W ciągu 15 lat funkcjonowania audytu zakres działań audytorów wewnętrznych wzrastał sukcesywnie, o czym świadczy wzrost liczby wykonanych czynności audytowych w latach 2011-2015. 


\section{Efektywność czynności doradczych}

Jak wynika z ustawy o finansach publicznych, system audytu to system o charakterze doradczym. W Międzynarodowych Standardach Praktyki Zawodowej Audytu Wewnętrznego usługi doradcze są określane, jako czynności, które ze względu na swój charakter są wykonywane zwykle w odpowiedzi na konkretne zapotrzebowanie zleceniodawcy (Komunikat Ministra Rozwoju i Finansów z 12 grudnia 2016 r. w sprawie standardów audytu wewnętrznego dla jednostek sektora finansów publicznych, Dz. Urz. Min. Rozw. i Fin. poz. 28). Według polskich regulacji, usługi doradcze mogą być świadczone na konkretne zlecenie kierownika jednostki lub jako część rocznego planu audytu. Czynności doradcze mogą być realizowane jako oddzielne zadanie lub część zadania zapewniającego. Wynikiem przeprowadzonych czynności doradczych są zalecenia bądź opinie, ewentualnie wnioski audytora wewnętrznego przedstawione kierownikowi jednostki (Rozporządzenie Ministra Finansów z dnia 4 września 2015 r. w sprawie audytu wewnętrznego oraz informacji o pracy i wynikach tego audytu; Dz.U. poz. 1480).

O ile zalecenia są częścią sprawozdania z audytu i mają na celu usprawnienie prowadzenia audytowanej jednostki, to opinie i wnioski nie są wiążące. Niewdrożenia wniosków nie trzeba nawet uzasadniać.

Do czynności doradczych audytora wewnętrznego wspomagających zarządzanie jednostką zalicza się:

- usprawnienie danego procesu działania,

- udział w projektowaniu poszczególnych procesów,

- udział w projektach w charakterze konsultanta,

- opiniowanie, doradztwo i konsultowanie procesów wdrażanych, jak i realizowanych,

- opiniowanie i poradnictwo w zakresie rozwiązywania problemów,

- udział w zebraniach i spotkaniach w celu wymiany informacji,

- przeprowadzanie szkoleń pracowników,

- doradztwo świadczone na rzecz poszczególnych komórek organizacyjnych.

Ilość czynności doradczych zależy od oczekiwań kierownictwa, od stopnia poznania organizacji i jej charakteru. Efektywność czynności doradczych uzależniona jest od czasu pracy, mierzonego w osobodniach, poświęconego na ich wykonanie. Przeciętny czas realizacji zadań audytowych w sektorze administracji rządowej przedstawiono w tabeli 3.

W analizowanym okresie nastąpił znaczny przyrost przeciętnego czasu na realizację czynności doradczych z 5 osobodni w 2011 roku do 55 osobodni w 2015 roku. Powinno się to przyczynić do skutecznego i efektywnego wspomagania zarządzania jednostkami, a także do doskonalenia systemu zarzadzania. $Z$ drugiej strony wielomiesięczne działania realizowane $w$ ramach audytu wpływają na bieżące zarządzanie daną jednostką.

Zgodnie z art. 275 ustawy o finansach publicznych (Dz.U. 2016, poz. 1870 z późn. zm.) audyt wewnętrzny może prowadzić audytor wewnętrzny zatrudniony w jednostce lub usługodawca, według wymogów art. 286 tej ustawy. Spełnienie przez nich tych samych 
warunków w zakresie wymaganych kwalifikacji i doświadczenia ma gwarantować uzyskanie takiej samej wartości dodanej.

\section{Tabela 3}

Czas realizacji czynności audytowych w jednostkach administracji rządowej w latach 2011-2015

\begin{tabular}{lrrrr}
\hline Czynności audytowe & 2011 & 2012 & 2014 & 2015 \\
\hline Przeciętny czas realizacji czynności zapewniających (w osobodniach) & 40 & 41 & 47 & 49 \\
Przeciętny czas realizacji czynności doradczych (w osobodniach) & 5 & 48 & 61 & 55 \\
Przeciętny czas realizacji czynności sprawdzających (w osobodniach) & 8 & 5 & 7 & 6,8 \\
$\begin{array}{l}\text { Procent wykorzystanych osobodni na zadania audytowe i czynności } \\
\quad \text { sprawdzające }\end{array}$ & 59 & 66 & 64 & 64 \\
\hline
\end{tabular}

Źródło: opracowanie własne na podstawie Departament (2012, 2012a, 2013, 2015, 2015a, 2016, 2016a).

Zestawienie czasu pracy i udziału czynności doradczych wykonywanych przez audytora zatrudnionego przez jednostkę i usługodawcę zaprezentowano w tabeli 4.

\section{Tabela 4}

Czas realizacji i udział czynności doradczych wykonywanych przez audytora wewnętrznego i usługodawcę w jednostkach administracji rządowej w latach 2011-2015

\begin{tabular}{lrrrc}
\hline Czynności doradcze & 2011 & 2012 & 2014 & 2015 \\
\hline Przeciętny czas realizacji czynności doradczych (w osobodniach) & & & & \\
- wykorzystany przez audytora zatrudnionego przez jednostkę & 64 & 70 & 64 & 63 \\
- wykorzystany przez usługodawcę & 5 & 8 & 12 & 22 \\
\hline Udział czynności doradczych (\%) & & & & \\
- wykonywanych przez audytora zatrudnionego przez jednostkę & 90 & 95 & 90 & 88 \\
- wykonywanych przez usługodawcę & b.d. & 44 & 65 & 70 \\
\hline
\end{tabular}

Źródło: opracowanie własne na podstawie Departament (2012, 2012a, 2013, 2015, 2015a, 2016, 2016a).

Z danych zawartych w tabeli 4 wynika, że w latach 2011-2015 udział czynności doradczych wykonywanych przez audytorów wewnętrznych zatrudnionych w jednostce administracji rządowej wynosił około 90\%. Nastąpił wzrost udziału czynności doradczych wykonywanych przez usługodawcę w ramach zadań audytowych z 44\% w 2012 roku do 70\% w 2015 roku. Spowodowane to było zwiększeniem liczby jednostek korzystających ze świadczeń usługodawcy w tym zakresie.

Zróżnicowanie formy prowadzenia audytu wewnętrznego wpływa na występowanie różnic w zakresie przeprowadzania czynności audytowych. Audyt prowadzony przez etatowego audytora wewnętrznego jest realizowany w większym zakresie niż w jednostkach, w których jest on prowadzony przez usługodawcę. Liczba osobodni przeznaczonych na realizację zadania audytowego przez audytora zatrudnionego w ramach umowy o pracę jest większa niż w sytuacji usługodawcy. Audyt przeprowadzony przez usługodawcę może być pozbawiony niezależności, obiektywizmu i zarazem wykazywać negatywny wpływ 
na efektywność i skuteczność audytu. Sprzyja temu między innymi brak stałego kontaktu usługodawcy z kierownikiem jednostki, brak systematyczności w dokonywaniu oceny kontroli zarządczej, zmniejszanie liczby zadań audytowych do realizacji, w celu ograniczania kosztów audytu.

Liczba zrealizowanych zadań, czy liczba sporządzonych sprawozdań z zadań nie odzwierciedla skuteczności badań. Nie wszystkie jednostki administracji rządowej, zobligowane ustawą o finansach publicznych, przekazują informację o realizacji zadań z zakresu audytu wewnętrznego. Wielkość jednostki i procesy w niej zachodzące wpływają w różny sposób na działania doradcze. Poza tym niewystarczająca obsada kadrowa komórek audytu wywiera negatywny wpływ na efektywność audytu wewnętrznego (Kaczmarczyk, Kaczmarczyk, 2012).

\section{Uwagi końcowe}

Audyt wewnętrzny jako nowoczesny instrument kontroli jest coraz szerzej wykorzystywany w procesie zarządzania. Wskazuje kierunki zmian, szacuje poziom ryzyka przy podejmowaniu konkretnych działań, określa zagrożenia związane z wydaniem błędnych decyzji. Jego głównym zdaniem jest badanie i ocena zarówno systemu zarządzania daną jednostką sektora publicznego, jak i sytemu kontroli zarządczej. Od stopnia świadomości istotności audytu wewnętrznego w procesie zarządzania zależy jego użyteczność i przydatność. Staje się wówczas pomocnym źródłem informacji o działalności danej jednostki. Audyt wewnętrzny powinien pełnić przede wszystkim rolę doradczą, a tym samym zapewnić możliwość ustawicznego doskonalenia jednostek. Głównym zadaniem audytu wewnętrznego jest dlatego udzielanie porad dotyczących zarządzania ryzykiem, kontroli, edukowanie pracowników w zakresie ryzyka i kontroli oraz upewnianie kierownika jednostki o prawidłowości i efektywności zachodzących w niej procesów (Kabalski, Grzesiak, 2017). Właściwie realizowana funkcja doradcza jest możliwa dzięki wiedzy audytora o wszystkich zachodzących w jednostce procesach i kompetencji audytorów. Tylko wówczas możliwe jest wskazanie właściwych możliwości usprawnień i rozwoju organizacji, identyfikowanie szans i zagrożeń, wychwytywanie błędów i nieprawidłowości czy oszustw i nadużyć. Ciągłe doskonalenie procedur audytu wewnętrznego jest niezbędne, aby efektywnie i skutecznie zarządzać podmiotami sektora finansów publicznych.

\section{Literatura}

Brzozowska, K. (2008). Audyt wewnętrzny w jednostkach rządowych sektora finansów publicznych. Zeszyty Naukowe Uniwersytetu Szczecińskiego, 512. Finanse, Rynki Finansowe, Ubezpieczenia, 12, 75-83.

Czerwiński, K. (2004). Audyt wewnętrzny. Warszawa: InfoAudit.

Departament Audytu Sektora Finansów Publicznych (2012). Benchmarking audytu wewnętrznego w jednostkach sektora finansów publicznych. Raport na podstawie danych za 2011 rok. Pobrane z: http://www.mf.gov.pl/c/ document_library/get_file?uuid=17e21728-3fd1-4714-9322-e8c018440b95\&groupId=764034 (29.05.2017). 
Departament Audytu Sektora Finansów Publicznych (2012a). Prowadzenie audytu wewnętrznego w jednostkach sektora finansów publicznych przez ustugodawcę. Pobrane z: http://www.mf.gov.pl/c/document_library/get_file? uuid=ea72085d-3c36-451a-a982-a08eb95e80b4\&groupId=764034 (3.06.2017).

Departament Audytu Sektora Finansów Publicznych (2013). Benchmarking audytu wewnętrznego w jednostkach sektora finansów publicznych. Raport na podstawie danych za 2012 rok. Pobrane z: http://www.mf.gov.pl/c/ document_library/get_file?uuid=edbd119f-6172-451b-9618-bd822fb3e59b\&groupId=764034 (29.05.2017).

Departament Polityki Wydatkowej (2015). Benchmarking audytu wewnętrznego $w$ jednostkach sektora finansów publicznych. Raport na podstawie danych za 2014 rok. Pobrane z: http://www.mf.gov.pl/c/docu-ment_library/ get_file?uuid=d9db1fde-e797-44ae-a100-566db3264ce3\&groupId=764034 (29.05.2017).

Departament Polityki Wydatkowej (2015a). Ocena funkcjonowania audytu wewnętrznego $w$ jednostkach sektora finansów publicznych w roku 2014. Pobrane z: http://www.mf.gov.pl/c/document_library/get_file?uu $\mathrm{id}=80 \mathrm{~d} 4 \mathrm{~d} 6 \mathrm{f3}-\mathrm{b} 741-45 \mathrm{~d} 1-94 \mathrm{~b} 1-1 \mathrm{e} 207 \mathrm{eb} 38 \mathrm{cae} \&$ groupId=764034 (3.06.2017).

Departament Polityki Wydatkowej (2016). Benchmarking audytu wewnętrznego $w$ jednostkach sektora finansów publicznych. Raport na podstawie danych za 2015 rok. Pobrane z: http://www.mf.gov.pl/c/ document_library/ get_file?uuid=2eb555cb-0e76-4ace-a366-08648ab34a72\&groupId=764034 (29.05.2017).

Departament polityki Wydatkowej (2016a). Ocena funkcjonowania audytu wewnętrznego w jednostkach sektora finansów publicznych w roku 2015. Pobrane z: http://www.mf.gov.pl/c/document_library/get_file?uu $\mathrm{id}=6089$ f063-22fd-41df-a06e-9d03add0c572\&group Id=764034 (3.06.2017).

Kabalski, P., Grzesiak, L. (2017). Funkcja audytu wewnętrznego w opinii polskich audytorów. Zeszyty Teoretyczne Rachunkowości, 91 (147), 9-20. DOI: 10.5604/01.3001.0009.8022.

Kaczmarczyk, A., Kaczmarczyk, J. (2012). Audyt efektywności w jednostkach sektora finansów publicznych. Zeszyty Naukowe Wyższej Szkoty Oficerskiej Wojsk Lądowych, 3 (165), 358-365.

Komunikat Ministra Rozwoju i Finansów z dnia 12 grudnia 2016 r. w sprawie standardów audytu wewnętrznego dla jednostek sektora finansów publicznych (Dz. Urz. Min. Rozw. i Fin. poz. 28).

Międzynarodowe Standardy Praktyki Zawodowej Audytu Wewnętrznego 2012, Tłum. IIA - Polska, Warszawa.

Rozporządzenia Ministra Finansów z dnia 24 czerwca 2006 r. w sprawie kwot, których przekroczenie powoduje obowiązek prowadzenia audytu wewnętrznego w jednostkach sektora finansów publicznych (Dz.U. nr 112, poz. 763).

Rozporządzenie Ministra Finansów z dnia 4 września 2015 r. w sprawie audytu wewnętrznego oraz informacji o pracy i wynikach tego audytu (Dz.U. poz. 1480).

Saunders, E.J. (2002). Audyt i kontrola wewnętrzna w przedsiębiorstwach. Częstochowa: Edukator.

Szymańska, H. (2012). Ogólne zagadnienia audytu wewnętrznego. W: T. Kiziukiewicz (red.), Zasady audytu wewnętrznego w sektorze finansów publicznych (s. 13-39). Warszawa: Difin.

Ustawa z dnia 26 listopada 1998 r. o finansach publicznych (Dz.U. 2001, nr 88 poz. 148 z późn. zm.).

Ustawa z dnia 30 czerwca 2005 r. o finansach publicznych (Dz.U. nr 249, poz. 2104 z późn. zm.).

Ustawa z dnia 27 sierpnia 2009 r. o finansach publicznych (t.j. Dz.U. 2016, poz. 1870 z późn. zm.).

\section{THE COURSE OF THE AUDIT TASKS IN UNITS OF GOVERNMENT}

Abstract: Purpose - To present the process of implementation of the audit activities in units of Government. Design/methodology/approach - Analysis of a law regulation, literature and studies of the Ministry of Finance to assess the functioning of the internal audit units of the public finance sector.

Findings - A compilation of information on implementation of audit tasks in units of Government in the years 2011-2015.

Originality/value - To draw attention to the aspect of the improvement of the measurement of the efficiency of advisory activities.

Keywords: internal audit, the advisory function, government sector, audit activities

\section{Cytowanie}

Wawer-Bernat, J. (2017). Przebieg realizacji czynności audytowych w jednostkach administracji rządowej. Finanse, Rynki Finansowe, Ubezpieczenia, 3 (87/1), s. 121-128. DOI: 10.18276/frfu.2017.87/1-11. 